\title{
REINTEGRATION OF RELIGIOUS KNOWLEDGE AND GENERAL KNOWLEDGE (CRITICISM OF THE DISCOURSE OF SCIENCE DICHOTOMY)
}

\author{
Fajar Syarif \\ Institut Ilmu Al-Qur'an (IIQ) Jakarta \\ fajarsyarif@iiq.ac.id
}

\begin{abstract}
This article aims to determine the implications that can arise from the dichotomy of science. Namely the emergence of a gap between the source of knowledge in the form of religious knowledge and general knowledge. Proponents of the religious knowledge only consider the divine source valid in the form of scriptures and prophetic traditions and reject non-scriptural sources as an authoritative source to explain true truth. On the other hand, secular scientists only consider valid information obtained through sensory observation. The method used in this study is qualitative with a phenomenological approach. Data collection was conducted through observation, in-depth interviews, documentation analysis and focused group discussion. This research shows that there is really no sorting of science and religion. The research findings provide an overview of science and the knowledge of religion is integral. If science is addressed with a dichotomy, it will certainly give birth to different thoughts in building world civilization.
\end{abstract}

Kata Kunci: pengetahuan, dikotomi

\begin{abstract}
Abstrak: Artikel ini bertujuan untuk mengetahui implikasi yang bisa muncul dari dikotomi ilmu. Yaitu timbulnya kesenjangan antara sumber ilmu, yaitu ilmu-ilmu agama dan ilmu-ilmu umum. Para pendukung ilmu-ilmu agama hanya menganggap valid sumber ilahi dalam bentuk kitab suci dan tradisi kenabian dan menolak sumber-sumber non-skriptual sebagai sumber otoritatif untuk menjelaskan kebenaran sejati. Dipihak lain, ilmuan-ilmuan sekuler hanya menganggap valid informasi yang diperoleh melalui pengamatan inderawi. Metode yang digunakan dalam penelitian ini adalah kualitatif dengan pendekatan fenomenologis. Pengumpulan data dilakukan melalui observasi, wawancara mendalam, analisis dokumentasi dan focused group discussion. Penelitian ini menujukkan bahwa sesungguhnya tidak ada pemilahan ilmu pengetahuan dan agama. Teтuan penelitian memberikan gambaran tentang ilmu pengetahuan dan ilmu agama merupakan sesuatu yang integral. Bila ilmu disikapi dengan dikotomi maka tentu akan melahirkan pemikiran yang berbeda dalam membangun peradaban dunia.
\end{abstract}

Keywords: knowledge, dichotomy

Islam is a religion that has various kinds of knowledge, both religious knowledge and general knowledge. In Islam knowledge is not distinguished, even Islam considers both knowledge like a currency that has two different sides but 
cannot be separated from each other. Today we are familiar with the title Islamic Studies and General Sciences. Islamic studies based on revelation, the hadith of the Prophet, reasoning and facts of history have developed so rapidly, for example kalām knowledge (theology) fiqih knowledge (Ușūl al-Fiqh), Philosophy, Sufism, Tafsīr ('Ulūm al-Tafsīr), hạāìth ('Ulūm al-Ḥadīth), Islamic History and Civilization, Islamic Education, Islamic Da'wah.

Furthermore, general knowledge based on reasoning and empirical data also experienced a more rapid development compared to Islamic knowledge. This general knowledge can be broadly divided into three parts: First, general knowledge that is characterized by naturalism with the universe and physical as the object of study, for example; Physics, Biology, Medicine, Astronomy, Geology, Botany and so on. This knowledge is then called science. Second, general knowledge that is Sociologically patterned with social/human behavior as the object of its study, which includes Anthropology, Sociology, Politics, Economics, Education, Communication, Psychology and so on. Third, general knowledge that is characterized by philosophical reasoning, such as; Philosophy, Logic, Art and other Humanities knowledge Many factors cause these knowledge not harmonious or dichotomous. In religious knowledge, for example, such disharmony is caused by the interests of political groups, methods of thinking and the schools of belief, situations and conditions in which a mujtahid resides, intelligence and educational background and other social relations. Whereas in general knowledge differences occur, among others, due to differences in methods and approaches used, socio-political situations, individual tendencies, intelligence and limited knowledge, and ideology that he believes. The occurrence of the dichotomy between Islamic knowledge and general knowledge is partly due to differences in the ontology, epistemology and axiology of the two fields. As it is known that the knowledge of Islam departs from revelation which is absolutely true and aided by reasoning in the process of its use must not conflict with revelation. Meanwhile the general knowledge that has existed so far comes from the West and is based on an atheistic, meterialistic, secular, empirical, 
rationalistic, even hedonistic philosophy. The two things that form the basis of these two knowledge are clearly very different and difficult to find.

One effort to overcome this situation is by integrating internal religious knowledge and general knowledge. This effort needs to be done if we do not want a situation that would endanger the future of humanity. Efforts to integrate religious knowledge and general knowledge were introduced by visionary experts since the end of the 20th century, which led to pros and cons. On the one hand there were those who agree about the Islamization of the knowledge and on the other hand there were those who disagree. This attitude is similar to the attitude shown by Muslims when responding to various socio-political problems.

In Fazlur Rahman's analysis, it was stated that since the classical period (850 AD - 1200 AD) until the early medieval period (1200 AD - 1800 AD), Muslims had a wealth of knowledge. However, entering the middle age until the end of the 19th century, Muslims experienced a setback, especially in the field of education. Realize it or not, knowledge seems to be separated into "religious and general knowledge".

Many factors cause these knowledge not harmonious or dichotomous. In religious knowledge, for example, such disharmony is caused by the interests of political groups, methods of thinking and the schools of belief, situations and conditions in which a mujtahid resides, intelligence and educational background and other social relations. Whereas in general knowledge differences occur, among others, due to differences in methods and approaches used, socio-political situations, individual tendencies, intelligence and limited knowledge, and ideology that he believes. The occurrence of the dichotomy between Islamic knowledge and general knowledge is partly due to differences in the ontology, epistemology and axiology of the two fields. As it is known that the knowledge of Islam departs from revelation which is absolutely true and aided by reasoning in the process of its use must not conflict with revelation. Meanwhile the general knowledge that has existed so far comes from the West and is based on an atheistic, meterialistic, secular, empirical, rationalistic, even hedonistic 
philosophy. The two things that form the basis of these two knowledge are clearly very different and difficult to find.

One effort to overcome this situation is by integrating internal religious knowledge and general knowledge. This effort needs to be done if we do not want a situation that would endanger the future of humanity. Efforts to integrate religious knowledge and general knowledge were introduced by visionary experts since the end of the 20th century, which led to pros and cons. On the one hand there were those who agree about the Islamization of the knowledge and on the other hand there were those who disagree. This attitude is similar to the attitude shown by Muslims when responding to various socio-political problems.

In Fazlur Rahman's analysis, it was stated that since the classical period (850 AD - 1200 AD) until the early medieval period (1200 AD - 1800 AD), Muslims had a wealth of knowledge. However, entering the middle age until the end of the 19th century, Muslims experienced a setback, especially in the field of education. Realize it or not, knowledge seems to be separated into "religious and general knowledge".

\section{The Emergence of Non-dichotomic and Dichotomic Era}

History records that Islamic civilization was once the center of knowledge of the world around the 7th century AD until the 15th century AD. After that, the golden age began to wilt, static, and even retreat until the 21 st century AD. When it became a center of knowledge, developing Islamic education was in the form of non-dichotomous Islamic education which eventually was able to give birth to Muslim intellectuals who had very large works and had a positive influence on the existence of human life. According to Harun Nasution, Islamic scholars did not only study science and philosophy from Greek books, but added to the results of the investigations they carried out in the field of science and their ideas in philosophy. Thus, Islamic scientists and philosophers were born, such as Ibn Haytham (d. 1039) a pioneer in the field of optics with his optical dictionary (kitab al-Manāzirir), al-Tūsi (d. 1274) veteran astronomer who did research on the movements of planets, making planetary models, al-Farazi (Islamic astronomer), 
Ibn Sina (medical expert, called doctor of doctors, Avicena), al-Biruni (philosopher, astronomer, geography, mathematics, also history), Ibn Rushd (philosopher and expert on jurisprudence, so called Averous), al-Khawarizmi (mathematician, so called Algorismus), Ibn al-Haitam (astronomer, so called alHazen). Whereas in the knowledge of religion, there are scholars who develop the science of hadīth (Bukhāri Muslim 9th century AD), the science of Islamic law (Imām Abū Hanīfah, Imām Mālik, Imām Shāfi'ī and Ibn Hambal 7th, 9th century) and etc.

Meanwhile, in the time and post of al-Ghazālī (d. $1111 \mathrm{M}$ ) and Ibn Khaldun (d. 1406) began dichotomous discourse of knowledge which was caused by the opinion of al-Ghazālī who viewed as fardhu 'ain to demand "religious knowledge" and fardhu kifayah for "non-religious knowledge" which has created significant inequality between the two classifications of knowledge. Not only did al-Ghazāli in his book "Tahafut al-Falasifah" issue fatwas that were "blind" to forbidding philosophy and forgiving those who studied and taught it. In his hands, the Islamic world is filled with mysticism. In this case, for Sayyed Hossein Nasr, al-Ghazālī's attack on philosophy was considered to have paralyzed rationalistic philosophy and finished the period of philosophy as a different discipline from gnosis and technology throughout the Arab region in the Islamic world. Although al-Ghazālī's attitude finally received a response and frontal attack with an academic-critical evaluation of Ibn Rushd in "Tahafut al-Tahafut" (ambiguous in confusion). Even if it was studied in a "mischievous manner", al-Ghazālī was the person most responsible for the collapse of the brilliance Islamic civilization, thus, the Orientalist Philip K. Hitti labeled him an anti-intellectual person.

On the other hand, if traced from historical data, actually the dichotomy of knowledge does not only occur among Muslims themselves, but also has happened before, especially among Christians in the dark age of Europe. At that time Europe was under authoritarian rule of the church, especially after the Roman king Constantine converted to Christianity. Christianity officially became a state religion and a ruling religion, so that over time the authority of the Pope and the leaders of Christianity became so great that the kings in the West were 
obliged to submit to them, and in the Middle Ages people were considered undervalued, while truth was measured by recognition from Church (Christian), not a measure made by humans.

At this stage, the Pope and Christian leaders at that time established several theories of knowledge and purified them into theories or even postulates which "the truth is indisputable". With this forced authority emerged the authoritarian attitude of the church itself in establishing its power, so that anyone who opposed it would face a trial in the Church court (inquisition). The people who were tried up to 300,000 people, 32,000 of them got punishments with rewards burned alive. Among them are two well-known scientists, Giordano Bruno and Galileo Galilei. Giordano Bruno is considered to be against the church because he says that nature is numerous. While Galileo Galilei said that the earth revolves around the sun (Heliocentris). The two scientific findings received a confrontational welcome from the church which indicated fear by this fact.

\section{Dichotomy of Knowledge in Islamic Perspectives}

Understanding the notion of dichotomy of knowledge, this of course must first focus on the literal meaning of the word "dichotomy" itself, because in this case the word "knowledge" is only an object. The word "dichotomy" comes from English "dichotomy" which means to distinguish and contrast two different things.

Classically in the Big Indonesian Language Dictionary, the dichotomy has the meaning of dividing two conflicting groups. Pius A. Partanto and M. Dahlan, al-Barry defines a dichotomy as a division in two conflicting parts. While Mujammil Qomar defines dichotomic as a division or two conflicting concepts and Jamaladdin Idris as quoted by Yuldelasharmi defines dichotomy as a careful and clear separation from one type into two where one cannot be put into the other and vice versa. Thus everything that divides something into two different groups and even contradicts one another is a dichotomy. Means, the definition of dichotomy is to distinguish, separate knowledge into two groups or two different and conflicting parts. 
The term dichotomy of knowledge in this research is the attitude or understanding that distinguishes, separates and contrasts between "religious knowledge" and "non-religious knowledge (general)". Some of the terms for this discourse are "knowledge of the hereafter" and "knowledge of the world". There are also those who refer to the knowledge of syar'iyyah and knowledge of ghair shar'iyyah, there are even other titles such as 'ulüm diniyyah and 'ulüm 'aqliyyah. So basically the knowledge is divided into two major parts, namely the knowledge of tanzilliyah in the form of knowledge developed by human reason related to the values revealed by Allah both in the book and the traditions of the Prophet Muhammad and Kauniyyah knowledge, namely the knowledge developed by human reason because of its interaction with nature. All classification of knowledge is to separate the two realms of knowledge. That is, all the existence of knowledge is contradicted and separated from one another in the frame of a segmented reality into a sub-system, each of which stands alone. Whereas in the theoretical-normative level, knowledge must be developed holisticallyintegratively and not partially, because the development of knowledge does not lead to dictomic goals, but leads to one virtue in the service of God.

Another term in dichotomy of knowledge that is more subtle at the root of science is the view of A. Malik Fadjar, he termed this dichotomy with hellenis for general knowledge or modern knowledge and semitic for religious knowledge. The idea of hellenis originated from classical Greece, whose prominent features gave a very large portion to the authority of reason, prioritizing rational attitudes and preferring secular knowledge. Whereas semitic ideas are related to the minds of religious people, especially Jews and Christians who predate Islam, with the characteristic of giving a very large portion to the authority of revelation, being obedient to dogma and oriented to religious knowledge. Another term revealed by Harun Nasution in the book "Islam Rasional", that he calls the attitude that separates these knowledge as "dualism of knowledge". In dualism, the most basic elements of each reality tend to be contradicted, but do not deny each other between them. For example crime and goodness, God and the universe, soul and body and so on. 
The definition of "Islamic perspective" in this context is a viewpoint in looking at the dichotomy of knowledge which is minimally viewed from the perspective of the Qur'an and as-Sunnah, because both are the main sources of Islamic law. Therefore, highlighting the dichotomy of knowledge from an Islamic perspective means highlighting it from the Qur'an and as-Sunnah. With this viewpoint, it produces a theoretical tracking structure that is inductiveconsultative or vice versa, deductive-consultative. Starting from the paradigm will lead to ways to obtain knowledge through two ways: First, knowledge obtained by axiomatic postulates given by reason and sensory perception, such bodies cannot be in two places simultaneously and the fire is hot. The knowledge obtained through reason postulates and sensory perception is referred to as al-ilm al-badihi. Second, knowledge gained through reasoning based on reason postulates and sensory perceptions, such as heated steel will melt which is the result of reasoning of all heated metals that will melt, while steel is a type of metal. Finally, from the two paths the results are consulted with "meta narratives", namely the Qur'an and al-Hadīth as the grand theory and the normative basis.

In Islamic teachings, the dichotomous attitude towards knowledge in an excessive, even discriminatory meaning is not found in the Qur'an and as-Sunnah, but what is found is the opposite, which is contrary to the holy message of the Qur'an which gives rise to the concept integral knowledge of the Qur'an and Hadīth. Both do not discriminate at all in mentioning and advocating the deepening of knowledge into the designation of "religious knowledge" and "nonreligious knowledge". In fact, the example of attitude of Prophet Muhammad and his companions until the next generation give a counter-productive example with excessive dichotomous attitudes towards knowledge.

We can study knowledge as the basis for the dichotomy and dualism in education and analyze the Qur'an and Hadīth, as revealed by Quraish Shihab, the word knowledge with its various forms repeated 854 times in the Qur'an and 750 verses al -Qur'an which talks about the material nature and its phenomenon. This implies that humans know and utilize this nature. The object of knowledge in Islam is divided into two major parts, namely material objects and non-material 
objects. As the Sufis introduced the knowledge they called al-Hadharat aJIlahiyah al-Khams (five divine presence) through the verses of the Qur'an as a description of the overall reality of being, namely the nature of nasüt (material nature), nature of malakūt (mental realm ), the nature of jabarūt (natural spirit), nature of laḥüt (divine attributes), and nature of hanūt (form of divine substance). In addition, there are many verses of the Qur'an which command to think about the universe, travel with the beginning and end because of Allah, as in Surah al'Alaq as the first letter revealed begins with the phrase "iqra" and ends with a sentence "wasjud waqtarib".

Our scholars have never distinguished between general knowledge and religion, all of them are important, only according to Muhamad Abduh, for example, there must be a priority scale where religious knowledge needs to be taught first because it relates to basic needs as religious people, they must know the nature of religion so they have an identity, a strong moral system and a clear vision.

The evidence that the 'Ulama (scholars) never negated certain disciplines can be seen from the scientific authority controlled by previous scholars. This indicates that Islam highly upholds the primacy of knowledge from the aspects of the integrity of the knowledge of Muslim leaders, the previous scholars also proved the unity of knowledge that must be studied. Al-Kindi, for example, was a philosopher and religious at the same time, so was al-Farābi. Ibn Sina, in addition to experts in the fields of medicine, philosophy, psychology, and music, he was also a scholar. Al-Khawarizimi was a scholar and a mathematician, al-Ghazālī, although later popular because of his life and sufistic teachings, in fact he had various fields of knowledge, ranging from fiqh, kalām, philosophy, to Sufism. Similarly, Ibn Rushd, a faqih who was able to write his magnum opus, namely Bidayat al-Mujtahid, was able to synergize philosophy and fiqh. Ibn Khaldun was known as the scholar who laid the foundations of modern sociology in his alMukaddimah magnum opus, which until now many experts have studied both from among Muslims and orientalists. 
So it can be said that people used to know almost no term dichotomy of knowledge. Because for them all that knowledge is in one roof of the building of thought and comes from God, the Essence of the One. There is no independent knowledge. Everything is interrelated, complementary. That might be the secret why people used to be able to produce weighty works and survive in the market for a very long time, they had interdisciplinary scientific authority. The concept of the dichotomy of knowledge entered together with the application of the dualism method of religious and non-religious knowledge (ilmi vs adabi). The project was promoted by Muhammad Ali Fasya, when he led Egypt. Precisely after being colonized by France, the intention was actually good. He wanted to advance Muslims through science and technology, but the method adopted was not appropriate because it produced a very dangerous scientific dualism. Normativelyconceptual, according to Abd. al-Raḥmān As-Segaf, dichotomy of science is not found in Islam. If we look at Islamic sources, namely the Qur'an and the Hadīth, we do not find either implicitly or even more explicitly found the argument about the dichotomy of knowledge, on the contrary, Islam teaches to demand all branches of knowledge.

Whereas according to Ramayulis, in Islamic education there is no separation between science and religion. Unification of both is a demand for Islamic faith. Allah in the doctrine of Islamic teachings is the creator of the universe including humans, and makes laws to manage and preserve it. The law regarding the physical realm is the sunnah of Allah, while the living guidelines and laws for human life are called din Allah. This implies that in education there is no justification for the dichotomy of religious education with science education. Students must understand Islam as a total way of life, at least an educator must be able to make changes in orientation to know the concept of knowledge that is directly linked to religious propositions or vice versa.

Looking at various negative impacts and implications of the dichotomy of religious knowledge (al-'ulüm al-diniyyah or religious sciences) with the general sciences, it is time for Muslims, especially Islamic institutions to carry out "reintegration of knowledge". So what is needed now is our view so far which still 
separates religious knowledge and general knowledge must be revolutionized. Sciences are seen as a single entity, which is equivalent to its hierarchy, which from an Islamic perspective, is equally rewarded if it demands and perseveres.

Although Islam teaches scientific integralism according to Azyumardi Azra, he calls it tawhidic paradigm of sciences at the conceptual level, but it must be admitted that at the practical level there is not infrequent disharmony, and the dichotomy between them, as explained above. Even dichotomies often reach epistemologies, namely between revelation and reason, or between "religious knowledge" and "general knowledge". Therefore, in order to overcome the disharmony of the dichotomy, Muslim thinkers and scientists offer a complete classification of knowledge with their respective hierarchies.

As stated by Nasr cited by Azyumardi Azra, various branches of knowledge and forms of knowledge viewed from Islamic perspectives in the end are one. In Islam itself there is really no essential separation between "religious knowledge" and "general knowledge". We can see this, for example, many Muslim intellectuals call al-Kindi, al-Farabi, Ibn Sina, until al-Ghazālī, Nașr alDīn al-Tūsisi, and Mulla Shadra in their various scientific disciplines and their respective intellectual perspectives developed together in the progress of Islam it does contain certain hierarchies, but in the end it will lead to the knowledge of " the essence of the One" which is the substance of all sciences. This is also proven and is the reason why Muslim thinkers and scientists tried to integrate the various knowledge developed by non-Muslim civilizations into the Islamic hierarchy of knowledge. We see, for example, one of the students of Imām Mālik, Al-Shāfi'ì (150-204 H), compiled a legal methodology which in addition could bring together the two camps. So that the conflict of the two camps, which produced an expression of freedom of thought, could be muted as early as possible. Shāfi'i formulated the fundamentals of thinking, which Fakhr al-Dīn al-Rāzī compared with Aristotle's position in the field of philosophy. If Aristotle succeeded in formulating a philosophical system with its mantiq (logic) methodology, al-Shāfi'i was considered to form ways of thinking in religion with its ushul fiqh methodology as stated in his master piece, al-Risalah. This means that this 
indicates in the determination of the basics of Islamic law (ushul fiqh) that touches on the philosophical tradition.

Besides Shāfi'ī, there was al-Kindi who was the first Muslim thinker to try to solve classification problems. The first classification is the al-'ulüm al'aqliyyah, which is the knowledge conveyed by God through revelation, but involves the use of reason. The second classification is al-'ulüm al-'aqliyyah, which is intellect knowledge, which is obtained mainly by the use of reason and empirical testing experience. In his work Fi Aqsam Al-'Ulūm (types of knowledge). He was followed by al-Farabi, who through his work Kitab al-'Ulūm (Book of the Knowledge Hierarchy) has a wider influence. Other figures who were able to integrate knowledge were Ibn Sina, al-Ghazālī, and Ibn Rushd who were all able to become scientific references to the Western world.

\section{Integration and Islamization of Knowledge}

On the issue of dichotomy, one of Fazlur Rahman's approaches is to accept modern secular education as it has generally developed in the Western world and try to "Islamize" it by filling it with certain key concepts of Islam. Furthermore, the problem is how to modernize Islamic education, which is to make it able to produce creative Islamic intellectuals in all fields of intellectual business together with a serious attachment to Islam. A. Syafi'i Ma'arif said that if the dichotomous dualism concept was successfully overthrown, then in the long run the Islamic education system would also change as a whole, starting from the elementary level to the university level.

According to Ramayulis, the solution is to reduce or stop the dichotomy in education based on the principles of balance that underlie Islamic education, namely the balance between worldly and spiritual life, the balance between body and spirit and the balance between individuals and society. According to Kamal Muhammad Isa, the main mistake of mankind that has been going on continuously is the separation between science and religion, even religion is considered as the enemy of science, a barrier to science, or at best only regarded as a substitute for science. Whereas religion is the basic framework of every 
science and culture, which is a source for the growth of science and culture itself. Religion is the only basis and source that regulates all the problems of human life. People who study the Qur'an carefully and thoroughly will find some of the verses called various facts and events as muqaddimah which then arrive at Allah as a decision called theory, while verses that state life as the topic of knowledge are called practical knowledge.

The next solution is the integration of knowledge, before that let us see in the Qur'an the word knowledge with its various forms repeated 854 times. This word is used in the sense of the process of attaining knowledge and objects of knowledge. Ilm, in terms of language, means clarity, therefore everything in the form of its root means clarity. Consider for example the word 'alam (flag), 'ulmat (cleft lip), 'alam (mountains), 'alamat (address), and so on. Knowledge is a clear thing about something. Even so, this word is different from 'arafa (knowing), a'rif (the omniscient), and ma'rifah (knowledge). So it is natural that Islam as a religion that is a blessing for all nature has never distinguished religious knowledge and general knowledge.

The problem, categorization of general knowledge, and knowledge in Islam generally appears to be more driven by political interests. This can be seen prominently with the emergence of reasons for quantitative regional accumulation; and philosophy was more studied in Western countries and religion was studied in the Eastern countries, so this conflict became the contradiction of two scientific groups with the terms "West" and "East". In the Islamic view, it does not mean "West" is higher than "East" or vice versa.

Al-Faruqi offers the Islamization of knowledge in Islamic education, namely by merging two educational systems; traditional and modern, becoming an educational system that has Islamic insight. This is intended to eliminate the problem of the education system dichotomy that has been happening among the ummah. The idea of "Islamization of knowledge" in Islamic education contains a principle; that Western knowledge does not have to be rejected, but must go through a process of filtering which is carried out in accordance with Islamic rules so that it does not conflict with the message of the Qur'an and Hadith. The role of 
Islamization of knowledge in solving dichotomy problems in Islamic education is the spirit offered by al-Faruqi in order to solve the problem of the dichotomy of Islamic education. According to al-Faruqi, Muslim academics must master all modern disciplines, understand the discipline perfectly, and feel it as a religious order. After that they must integrate the new knowledge into the integrity of Islamic heritage by eliminating, changing, reinterpreting, and adjusting to its components as an Islamic world view and establishing its values.

It must be admitted that in the present era, Islamic knowledge lags far behind the West. Refusing knowledge that comes from the West clearly alienates ourselves from the times and is unrealistic, and it will make the Muslims more left behind. While accepting Western knowledge that tends to be secular in full is feared to undermine Islamic teachings that are full of normativity. This is the time for Muslim scholars to abandon dangerous imitation methods in educational reform. According to al-Faruqi, the reform towards the modernization of Islamic education should be the Islamization of modern knowledge itself. So the task of Muslims is the same, even with a wide range, compared to those of the ancestors of the people who digest the knowledge of their time and produce Islamic heritage in the form of culture and civilization. Every discipline in literary, social and natural sciences must be compiled and rebuilt, given the basis of Islam, and given new goals consistent with Islam.

Every discipline must be poured back so that it embodies Islamic principles in the methodology, strategy, data, problems, goals and aspirations. Every discipline must be re-forged so as to reveal the relevance of Islam with the three axes of Tawheed. The first axis is the unity of knowledge. Based on this unity of knowledge all disciplines must look for rational objective values, namely critical knowledge of the truth. Thus there is no scientific dichotomy; aqli and naqli or scientific and dogma. The second axis is the unity of life. Based on this unity of life, all disciplines must be aware of and serve the purpose of creation. Thus there is no longer a statement that some disciplines have value while other disciplines are value-free or neutral. The third axis is historical unity. Based on this historical unity all disciplines will accept the ummah or social nature of all 
human activities, and take the goal of the people in history. Thus there is no division of knowledge in individual science and social science, so that each discipline is humanistic and ummatic.

\section{CONCLUSION}

Based on the explanation above, to overcome the dichotomy of knowledge, namely, trying to integrate general knowledge and religious knowledge organically and holistically: by incorporating general knowledge and religious knowledge, such as the social sciences, natural sciences, world history, and religious knowledge, such as: theology, fiqh, interpretation, hadīth into the curriculum or syllabus of Islamic education. Fazlur Rahman provides a solution for Islamic education which has experienced setbacks by (1) integrating religious and general knowledge (2) Islamization of science.

Islamization of knowledge is a moral responsibility of scientists in order to save humanity's civilization. Islamization of knowledge includes the term spiritualization and integration between religious knowledge and general knowledge. In relation to the Islamization of various knowledge, the first thing that has to go through the process of Islamization is science: present-day knowledge or contemporary knowledge. 


\section{REFERENCES}

Al-Faruqi, Isma'il Raji. Islamization of Knowledge: General Principles and Workplan. Hemdon : HIT. 1982.

As-Segaf, Abd. Rahman. Pengantar dalam buku Pendidikan Islam Integratif. Yogyakarta: Pustaka Pelajar. Cet Ke-1. 2005.

Azra, Azyumardi. Historiografi Islam Kontemporer: Wacana, Aktualitas dan Aktor Sejarah. Jakarta: Gramedia Pustaka Utama. 2002. - Paradigma Baru Pendidikan Nasional, Rekonstruksi dan Demokratisasi. Jakarta: Kompas. 2006.

Baharuddin, dkk. Dikotomi Pendidikan Islam. Bandung: PT Remaja Rosdakarya. 2011. Baso, Ahmad. NU Studies: Pergolakan Pemikiran antara Fundamentalisme Islam dan Fundamentalisme Neo-Liberal. Jakarta: Erlangga. 2006.

Bastaman, Hanna Djumhana. Integrasi Psikolgi dengan Islam: Menuju Psikologi Islami. Yogyakarta: Pustaka Pelajar. 2003.

Dahlan, Abdul Aziz. Teologi, Filsafat, Tasawuf dalam Islam. Jakarta: Ushul Press. 2012.

Echols, John M. Kamus Inggris-Indonesia: An english-Indonesian Dictionary. Jakarta: Gramedia. 2000.

Fadjar, A. Malik. Reorientasi Pendidikan Islam. Jakarta: Grafiti. Cet Ke-1. 2000.

Hasbullah, Moeflich. Gagasan dan Perdebatan Islamisasi Ilmu Pengetahuan. Jakarta: LSAF, Iris, Cidesindo. Cet Ke-1. 2000.

Hitti, Philip K. History of The Arab. London: Macmilan Press Ltd. 1974.

Isa, Kamal Muhammad. Manajemen Pendidikan Islam. Jakarta: Fikahati Aneska. 1994.

Khalaf, Abd. Wahab. Ilmu Ushul Fiqh. Beirut: Dar al-Fikr. Cet Ke-2. 1978.

Ma'arif, Ahmad Syafi'i. Pemikiran tentang Pembaharuan Pendidikan Islam di Indonesia, dalam Pendidikan Islam di Indonesia antara Cita dan Fakta. Yogyakarta: Tiara Wacana. 1991.

Ma'arif, Syamsul. Revitasi Pendidikan Islam. Yogyakarta: Graha Ilmu. 2007.

Mursyi, Ahmad Munir. Al-Tarbiyah al-Islamiyah: Ushuluha Wa Tathawwuruha. Kairo: Maktabah Dar al-'Alam. 1986.

Nasution, Harun. Akal dan Wahyu dalam Islam. Jakarta, UI Press. 1986. 
. Islam Ditinjau dari berbagai Aspeknya. Jakarta: UI Press. 1979. Pembaharuan Dalam Islam, Sejarah Pemikiran dan Gerakan. Jakarta: Bulan Bintang. Cet Ke-14. 2003 . Teologi (Ilmu Kalam). Jakarta: UI Press. Cet Ke-1. 1978

Nata, Abbudin. Ilmu Kalam, Filsafat dan Tasawuf. Jakarta: Rajawali. Cet. 11982. Integrasi Ilmu Agama dan Ilmu Umum. Jakarta: PT RajaGrafindo Persada. 2005.

Nizar, Samsul. Sejarah Pendidikan Islam: Menelusuri Jejak Sejarah Pendidikan Era Nabi Muhammad sampai Indonesia. Jakarta: Kencana. 2009.

Partanto, Pius A., M. Dahlan al-Barry, Kamus Ilmiah Populer. Surabaya: Arkola. 1994. Puradisastra. Sumbangan Islam Terhadap Peradaban Eropa Dan Barat. Jakarta: P3M. Cet Ke-1. 1980.

Qomar, Mujammil. Epistemologi Pendidikan Islam: Dari Metode Rasional Hingga Metode Kritik. Jakarta: Erlangga. 2006.

Rahman, Fazlur. Islam and Modernity: Transformation of An Intellectual Tradition. Chicago \& London: The University of Chicago Press. 1984.

Ramayulis. Ilmu Pendidikan Islam. Jakarta: Kalam Mulia. Cet Ke-8. 2010.

S. Wojowasito dan W J. S Poerwadarminta, Kamus Lengkap Inggris-Indonesia, Indonesia-Inggris. Bandung: Hasta. 1980.

Shihab, M. Quraish. Wawasan Al-Quran, Tafsir Maudhu'i atas Berbagai Persoalan Umat. Bandung: Mizan. 1996.

Suwito, dkk. Integrasi Ilmu Agama \& Ilmu Umum. Jakarta: PT RajaGrafindo Persada. 2005.

Syadzali, Munawir. Islam dan Ketatanegaraan. Jakarta: UI Press. Cet Ke-1. 1996.

Tim. Kamus Besar Bahasa Indonesia. Jakarta: Balai Pustaka. 2001.

Zaini, Syahminan. Integrasi Ilmu dan Aplikasinya Menurut Al-Qur'an. Jakarta: Kalam Mulia. 1989. 
